\title{
Duties And Authority Of PKPU Management Basen On Law No. 37 Of 2004 Concerning Bankruptcy And Suspension Debt Payment Obligations
}

\section{Zeffrianto Sihotang}

Sumatera University Faculty Of Law. E-mail: zeffriantos11@gmail.com

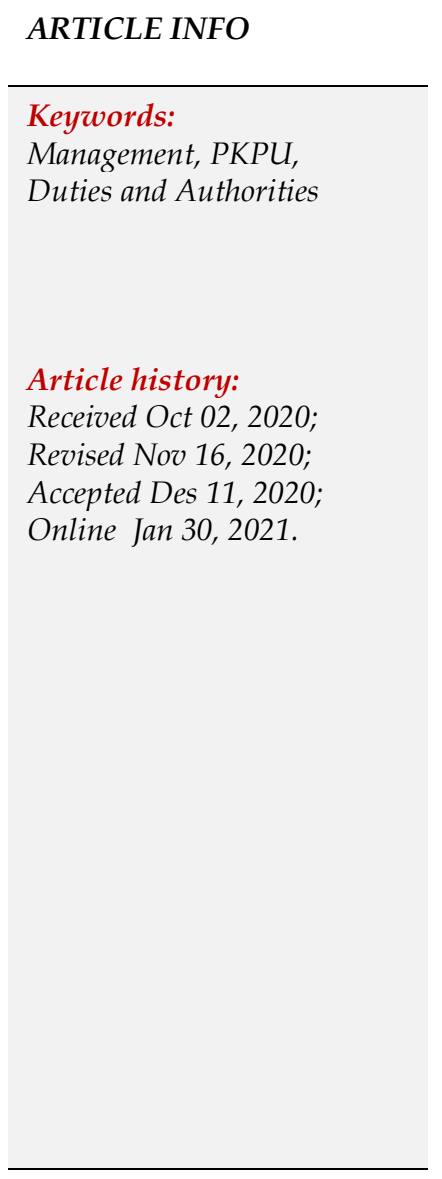

\begin{abstract}
Suspension of Debt Payment Obligations (PKPU) is a way that can be done so that debtors avoid the bankruptcy process. In the PKPU process, one or more independent PKPU administrators are appointed to together with the $P K P U$ debtor manage the assets of the PKPU debtor. The problem in this paper is about how the appointment of the management in PKPU, the relationship between the management and PKPU debtors, as well as the duties and authorities of the PKPU management as regulated in Law Number 37 of 2004 concerning Bankruptcy and Postponement of Debt Payment Obligations. The research method used is a normative legal research method with a descriptive research nature and uses a juridical legal approach. Data collection was carried out by means of data collection in the form of library research in the form of books, articles, magazines and the internet which are closely related to the aims and objectives of writing this thesis. The data used is secondary data, namely primary legal materials, secondary legal materials and tertiary legal materials. The method used in analyzing the data is qualitative analysis. The conclusion of this paper is that the PKPU management is appointed by the Panel of Judges of the Commercial Court who examines and decides on the PKPU case with a decision. In PKPU, the relationship between management and debtors is very close based on the duties and authorities they have, so that in order to achieve the goals of PKPU, the management and debtors must always pay attention to and maintain good relations. Law No. 37 of 2004 concerning Bankruptcy and Suspension of Debt Payment Obligations has regulated the duties and authorities of the PKPU management in managing the assets of PKPU debtors together with PKPU debtors treasure.
\end{abstract}

This is an open access article under the CC BY-NC license.

\section{Introduction}

In line with the development of national development, the development of the business world in Indonesia is also growing rapidly. This can be seen by the increasing number of entrepreneurs both acting individually and jointly establishing companies with the aim of making profits. Individuals and companies in running their business certainly need capital, both in the form of money and goods. The larger the business that will be run, of course, the greater the capital needed by the company. To meet the need for capital, they often make loans to the owners of capital/creditors. People/companies that receive loans from capital owners/creditors are generally called debtors. 
When running a business, it is likely that the debtor will experience a profit or loss. If the debtor experiences a profit, of course the debtor can survive and even continue to grow. However, in reality the debtor's condition is not always in good condition, debtors often experience financial losses or difficulties so that it is difficult to maintain the business and unable to pay their debts or it can be categorized that the company is experiencing corporate failure if the debtor is a company.

The provision of loans or credits given by creditors to debtors is carried out because of the belief that the debtor can return the loan to the creditor according to the agreement. That's why a loan from a creditor to a debtor is called credit, which comes from the word creder which means trust. ${ }^{2}$ For debtors, paying debts to creditors in accordance with the agreement of the parties is an obligation. If the obligation to pay the debt goes smoothly then of course there will be no problems. However, problems will arise when the debtor has difficulty paying his debts according to the agreement. In other words, the debtor is in a state of stopping paying debts, which of course will cause losses to the creditor.

Debtors who know that their financial situation is in trouble so that they are likely to stop paying their debts, then they can choose several steps to settle their debts, the steps referred to are making peace outside the court with their creditors or making peace in court if the debtor is sued in a civil manner. . Debtors can also apply for Suspension of Debt Payment Obligations (PKPU) and apply for reconciliation in PKPU. Another step is to file an application to be declared bankrupt by the court.

In relation to these alternatives, the debtor should choose the best alternative. One option is to apply for a PKPU. Suspension of Debt Payment Obligations is regulated in Law Number 37 of 2004 concerning Bankruptcy and Suspension of Debt Payment Obligations in Chapter III concerning Postponement of Debt Payment Obligations from Article 222 to Article 294.

Based on Article 222 paragraph 2 of the Bankruptcy Law and PKPU, a debtor who is unable or predicts that he will not be able to continue paying his debts that are due and collectible can request a postponement of debt payments, with a view to submitting a reconciliation plan which includes an offer of payment. all or part of the debt to creditors. Another term for this PKPU is suspension of payment or Surseance van Betaling, which means a period given by law through a commercial judge's decision in which during that period creditors and debtors are given the opportunity to discuss ways to pay their debts by providing a plan. payment of all or part of the debt, including if necessary to restructure the debt.

Based on Article 222 paragraph 3 of the Bankruptcy Law and PKPU, the PKPU application is not only made by the debtor, but also by the creditor who estimates that the debtor cannot continue to pay his debts that are due and collectible. This shows that PKPU is not intended for the benefit of the debtor only but also for the benefit of its creditors, especially concurrent creditors. The objectives of the PKPU itself are as follows: first, the debtor gets sufficient time to fix his difficulties, and is finally able to pay/repay his debts in the future; Second, it is possible for the creditor to get full payment of his receivables so that it does not harm him.

The implementation of PKPU is a way to avoid debtors from the bankruptcy process. However, sometimes the PKPU that is held is also unsuccessful, this can be caused by various factors that become obstacles, one of which is the lack of trust from new creditors to provide loans for the continuation of the debtor's business, or new creditors are willing to provide loans with conditions that are quite burdensome. debtors, so that instead of improving the company that will occur, quite the opposite. The postponement of Debt Payment Obligations requested by debtors and creditors should be carried out with sufficient care and full accuracy, because once the parties take a wrong step it can cause the destruction of the management of the debtor's company assets. 


\section{Method}

In this legal research, the researcher makes the field of legal science as the basis of the parent science, therefore the research used is legal research. According to Soerjono Soekanto, what is meant by legal research is scientific activity based on certain methods, systematics, and thoughts that aim to study one or all certain laws by analyzing them.

This type of research is normative legal research, also known as doctrinal research, which is a study that focuses on legal analysis, both laws written in books (law in books) and laws decided by judges through court decisions (law is decided by the law). judge through the judicial process).

This research is descriptive in nature which aims to accurately describe the individual nature of a particular symptom, situation or group. Analytical descriptive means that this research describes a legal regulation in the context of legal theories and their implementation and analyzes the facts carefully about the duties and authorities of the management in PKPU. The approach used in this research is a juridical approach, which is an approach that conceptualizes law as a norm, rule or principle with stages in the form of literature study with approaches from various literatures. The research method also combines library research using existing literature media and other electronic scientific journals such as the internet and juridical reviews. Processing, analysis and construction of normative legal research data can be done by analyzing the legal rules and then construction is carried out by entering articles into categories based on the basic understanding of the legal system.

\section{Analysis And Results}

\subsection{Relationship Of The Management With The Debtor In PKPU}

\section{a. PKPU Legal Consequences}

During the course of the PKPU, according to Article 242 paragraph 1 Article 240 paragraph 1 of the Bankruptcy Law and PKPU, debtors cannot be forced to pay their debts. In addition, all execution actions that have been initiated in the context of paying off debts must be suspended. It can be interpreted that this situation lasts both during the temporary PKPU and as long as the permanent PKPU.

1) Against the treasures of the union.

PKPU will bring legal consequences to all debtor's assets. For this reason, the Bankruptcy Law and PKPU distinguish between debtors who are married with a union of assets and those who are married without a union of assets. If the debtor is married in a union of assets, the debtor's assets include all assets and liabilities of the union (Article 241 of the Bankruptcy Law and PKPU). And the explanation of Article 241 states that what is meant by assets is the entire wealth of the debtor, while liabilities are all debts of the debtor.

2) For things that are going on.

The postponement of the obligation to pay debts does not stop the proceedings of cases that have already begun to be examined by the court, nor does it prevent the submission of new cases (Article 243 paragraph 1). However, if the case concerns a claim for payment of a receivable that has been recognized by the debtor, while the plaintiff has no interest in obtaining a decision to exercise rights against a third party, after the acknowledgment has been recorded. The judge can postpone the decision until the end of the PKPU. In this case the debtor cannot be

3) Creditors holding guarantees and maintenance costs. 
In PKPU, the exercise of the rights of creditors holding guarantees and privileged creditors is suspended for the duration of the PKPU (Article 246 of the Bankruptcy Law and PKPU).

4) Against debt payments.

Payment of all debts, other than those referred to in Article 244 of the Bankruptcy Law and PKPU that existed before the issuance of PKPU, during the course of PKPU may not be made, unless the payment of the debt is made to all creditors according to the balance of their respective receivables, without reducing the validity of the provisions of Article 245 verse 3

5) Debt encounter.

Settlement of debt can be done if both the debt and the receivable have been born before the commencement of the PKPU. The receivables from the debtor will be calculated according to the provisions of Article 274 and Article 275 of the Bankruptcy Law and PKPU. People who take over from a third party for debts to debtors or receivables from debtors from third parties before PKPU, cannot make a debt settlement if the takeover of these debts does not have good intentions. Receivables or debts taken over

6) Reciprocal agreement.

If at the time the PKPU decision is pronounced there is a reciprocal agreement that has not been or has only been partially fulfilled, then the party entering into the agreement with the debtor may request the management to provide certainty regarding the continuation of the implementation of the agreement within the period agreed upon by the management and the party.

\section{7) Delivery agreement.}

If it has been agreed that the delivery of objects that are normally traded for a period of time and before the delivery is made, the decision of the Temporary PKPU has been pronounced, then the result is that the agreement is null and void, and in the event that the opposing party is harmed by the abolition, he may.

\section{8) Lease agreement.}

In the event that the debtor has rented an object, the debtor with the approval of the management can terminate the lease agreement on the condition that the notification of termination is made before the expiration of the agreement in accordance with local customs.

\section{9) Work termination.}

Immediately after the promulgation of the Temporary PKPU decision, the debtor has the right to terminate the employment relationship with its employees, with due observance of the provisions of Article 240 and the period of time according to the approval or the provisions of the applicable laws with the understanding that the termination of employment can be terminated with a minimum notice of 45 (forty five) ) the previous day.

\section{b. Management position in PKPU}

Article 234 paragraph 1 of the Bankruptcy and PKPU Law stipulates that the appointed PKPU management must be independent and have no conflict of interest with debtors or creditors. The PKPU management appointed must be independent where he is a person or entity that is not under one of the parties to the dispute, so that his independence is truly maintained.

If, while carrying out management duties, the PKPU administrator finds out that he has a conflict with one or more creditors, the supervisory judge or members of the panel of judges of the commercial court handling the PKPU, ask the PKPU management to:

1) Notify in writing of the conflict of interest to the supervisory judge, debtor, creditor meeting and creditor committee, if any, with a copy to the honorary board of AKPI, and 
must immediately summon a creditors' meeting to be held as soon as possible specifically to decide on the conflict issue; or

2) immediately resign. If the PKPU management resigns, the PKPU management must call a meeting of creditors to appoint other PKPU administrators which is carried out in accordance with the provisions of the Bankruptcy and PKPU Law and the Professional Standards of Curators and Management.

The position and authority of the management is guaranteed by law to be able to act immediately, if necessary cancel all transactions made by the debtor without going through the approval of the PKPU management. This is solely done by the PKPU management to carry out their responsibilities so that creditors are not harmed because the law provides sanctions that if the management neglects to carry out their responsibilities and causes losses to both the debtor's assets and the interests of the creditor, a PKPU administrator can be asked to do so. liability in the form of compensation.

If the PKPU management does not give consideration or without proper research, then he is considered irresponsible. Therefore, the PKPU management must continuously monitor the business of the debtor. As soon as the PKPU management finds out that there is a reduced amount of fixed income or costs incurred from continuing the business beyond the maximum expected limit, the PKPU management must immediately stop and end the business of the debtor company.

\section{c. Relationship between Management and PKPU Debtors}

A curator in a bankruptcy replaces the position of the bankrupt debtor in managing his assets, but a PKPU administrator does not replace the debtor in the PKPU process. Because in principle one cannot act without the other. After the Court has determined the PKPU decision, the debtor is subject to restrictions on his freedom to manage and use his assets, where he is not allowed to manage his business without cooperation with the PKPU management. In this case the debtor does not lose his right to manage his assets as a result of the decision, but the debtor is given the authority to manage his company assets together with the PKPU management.

One of the factors that determine the success of PKPU administrators in their duties is how PKPU administrators can foster working relationships with debtors. In this case, debtors can be divided into two, namely, cooperative debtors and non-cooperative debtors. A debtor who is not cooperative can be judged if they refuse, whether or not requested by the PKPU management, to cooperate in carrying out the PKPU process. For uncooperative debtors, the management can propose to the supervisory judge to take legal actions so that the debtor can immediately comply with the ongoing process.

\subsection{Duties And Authorities Of Pkpu Managers In Law No. 37 Year 2004}

\section{a. Duties and Authorities of PKPU Management}

The main task of the management is to take care of the assets of PKPU debtors together with PKPU debtors. During the course of the PKPU, the PKPU debtor without the approval of the management cannot take management actions or ownership of all or part of his assets..$^{90}$ The duties and authorities of the PKPU Management are as follows:

1) Announce the PKPU decision in the State Gazette of the Republic of Indonesia and in at least 2 (two) daily newspapers appointed by the supervisory judge and the announcement must also contain an invitation to attend the trial which is a deliberation meeting of judges along with the date, place and time of the trial. the name of the supervisory judge and the name and address of the management. If at the time the temporary PKPU was pronounced, there was already a plan for reconciliation by the debtor. This is stated in the announcement and the announcement must be made within a maximum period of 21 
(twenty one) days prior to the planned trial date.

2) Announcing the bankruptcy decision as a result of temporary PKPU which has ended due to concurrent creditors not agreeing to provide a permanent PKPU, or permanent PKPU has been granted, but after the expiration of time, no agreement was reached on the peace plan.

3) Ask for advice from the creditors committee, if any.

4) Requesting the supervisory judge to summon witnesses or order an examination by an expert, in order to explain the situation concerning PKPU.

5) Submit a report to the supervisory judge every six months regarding the debtor's assets in its implementation.

6) Give approval to the debtor if the debtor files a lawsuit or is sued regarding the debtor's assets and if the debtor wants to terminate the lease agreement.

7) At the request of the debtor, the management provides certainty about the continuation of the implementation of the agreement between the debtor and other parties within the period agreed upon by the management and the other party.

8) Requesting the commercial court through the supervisory judge to terminate the PKPU, if the debtor during the PKPU acts in bad faith in managing his assets, or during the PKPU, the condition of the debtor's assets is no longer possible for PKPU to continue.

9) Make a list of receivables that contains the name of the creditor, the place of residence of the creditor, the amount of each receivable, and an explanation of the receivable. The list after being changed or added at the verification meeting and the amount is fixed (money and votes), must be signed by the supervisory judge and the substitute clerk, then the list has binding force and must be attached to the minutes of the meeting.

10) Provide a list of receivables to the clerk of the commercial court, no later than 7 (seven) days before the creditors' meeting, so that it can be viewed free of charge by anyone.

11) Provide a written report on the peace plan.

In addition to the above matters which are the duties of the PKPU management, the provisions of Article 239 paragraph 1 of the Bankruptcy Law and PKPU also require PKPU administrators to report every 3 (three) months the condition of the debtor's company assets. The report must be made available at the clerk's office of the commercial court so that it can be examined by the public free of charge. ${ }^{92}$ If the public or the public wants to obtain the report, it can also be obtained free of charge. Furthermore, the provisions of Article 239 paragraph 2 of the Bankruptcy Law and PKPU state that the supervisory judge is authorized to extend the reporting period for the management as referred to above. With the provisions of Article 239 paragraph 2, it means that the reporting period by the PKPU management as stipulated in Article 239 paragraph 1 is not too strict. Thus, if the PKPU management considers the threemonth period to be too short because the debtor's financial situation is not simple, for example a debtor who has a very large amount of debt, then the management can apply to the supervisory judge so that the periodization of the report can be relaxed.

\section{b. The Role of Administrators in the Peace Plan}

In the PKPU, the debtor is given the opportunity to make a peace plan, in which this peace plan will later be offered to the creditor, thus if this reconciliation is approved by the creditors, the debtor has the opportunity to continue the running of the company. ${ }^{100}$ The role of the PKPU management is also very decisive in the preparation of the peace draft. Because after all, the authority possessed by the management in accordance with court decisions is quite strong and is an important position in the process of implementing peace in PKPU.

The procedures for submitting peace proposals in the context of PKPU are as follows:

1) Plan peace submitted could together with submitted PKPU application (Article 224 paragraph 5 of the Bankruptcy Law and PKPU).

2) If the peace plan is submitted after the PKPU application has been submitted, it must be before the date of the trial at the latest according to the provisional PKPU provisions, i.e. 
before the 45 day deadline has passed, and the peace plan as intended must be made available at the Registrar's Office to be examined by anyone without being charged (charged) (Article 229 paragraph 3 of the Bankruptcy Law and PKPU) and must be submitted to the supervisory judge and administrators as well as experts, if any, as soon as possible after the plan is available.

3) If the reconciliation plan is attached to the request for a temporary suspension of debt payment obligations, or has been submitted by the debtor before the trial, the supervisory judge must determine;

a) The last day must be submitted to the management (Article 268 paragraph 1 letter a of the Bankruptcy Law and PKPU).

b) The date and time of the proposed reconciliation will be discussed and decided in a creditors' meeting chaired by a supervisory judge (Article 268 paragraph 1 letter b of the Bankruptcy Law and PKPU).

c) The grace period between points 1) and 2) is at least 14 (fourteen) days (Article 268 paragraph 2 of the Bankruptcy Law and PKPU).

4) The management is obliged to notify the matters mentioned above (point c) to all known creditors either by registered mail or by courier (Article 225 paragraph 4 of the Bankruptcy Law and PKPU).

5) For all claims submitted to the management by submitting invoices or other written evidence stating the nature and amount of the invoices accompanied by supporting evidence and for claims submitted to the management, the creditor may request a receipt from the management (Article 270 paragraphs 1 and 2 Bankruptcy Law and PKPU).

6) In the event that the provisions referred to above cannot be fulfilled, or if the creditors have not been able to cast their votes regarding the reconciliation plan, then at the request of the debtor, the creditors must determine the acceptance or rejection of the permanent suspension of debt payment obligations with the aim of enabling the debtor, management and creditor to consider and approve the reconciliation at the next meeting or trial (Article 228 paragraph 4 of the Bankruptcy Law and PKPU).

7) If the Permanent PKPU as referred to above is approved, then the postponement and its extension may not exceed 270 days as of the decision to postpone the temporary debt payment obligation (Article 228 paragraph 6 of the Bankruptcy Law and PKPU).

Creditors holding collateral rights who do not agree to the reconciliation plan are given compensation at the lowest value between the collateral value or the actual value of the loan which is directly guaranteed by the collateral rights to property. The provisions of Article 152 and Article 153 of the Bankruptcy Law and PKPU also apply in voting to accept the peace plan (Article 281 of the Bankruptcy Law and PKPU).

The minutes of the meeting chaired by the supervisory judge must include the contents of the reconciliation plan, the names of creditors present and entitled to cast votes, notes on the votes cast by creditors, voting results, and notes on all other events at the meeting. The list of creditors made by the PKPU management which has been added or changed at the meeting must be signed by the supervisory judge and the substitute clerk and must be attached to the minutes of the meeting concerned. A copy of the minutes of the meeting must be provided at the Court Registrar's Office no later than 3 (three) days after the decision of the meeting and can be seen by everyone free of charge for 8 (eight) days after the date it was provided (Article 282 of the Bankruptcy Law and PKPU).

If the reconciliation plan is agreed upon by the debtor and his creditors, with or without amendments, and after the agreement has been ratified by the commercial court, the peace agreement is binding on both the debtor and all creditors. ${ }^{106}$ The agreement on peace is stated in the peace agreement, and this peace agreement will be the basis of the agreement between the debtor and creditor further and this agreement is called the peace agreement. And the previous agreement regarding debts and debts became invalid after the peace plan was agreed. 


\section{c. PKPU termination}

After the PKPU is granted, the PKPU may be terminated either at the request of the supervisory judge or at the request of the management or at the request of one or more creditors, or at the initiative of the court itself in the following cases:

1) The debtor during the PKPU period acted in bad faith in managing his assets (Article 255 paragraph (1) letter (a) of the Bankruptcy Law and PKPU).

2) The debtor has or tried to harm his creditors (Article 255 paragraph (1) letter (b) of the Bankruptcy Law and PKPU).

3) The debtor commits a violation during the PKPU, the debtor without the approval of the management takes management actions or ownership of all or part of his assets. And if the debtor violates this provision, the management has the right to do everything necessary to ensure that the debtor's assets are not harmed because of the debtor's actions (Article 225 paragraph (1) letter (c) in conjunction with Article 240 paragraph (1) of the Bankruptcy Law and PKPU).

4) The debtor fails to carry out the actions required of him by the court at the time or after the suspension of the obligation to pay the debt is granted, or fails to carry out the actions required by the administrators for the benefit of the debtor's assets (Article 255 paragraph (1) letter (d) of the Bankruptcy Law and PKPU).

5) As long as the postponement of the obligation to pay debts on the debtor's assets is no longer possible to continue the suspension of debt payment obligations (Article 255 paragraph (1) letter (e) of the Bankruptcy Law and PKPU),

6) Debtors cannot be expected to fulfill their obligations to creditors on time (Article 255 paragraph (1) letter (f) of the Bankruptcy Law and PKPU).

In the event that the debtor has bad intentions during the PKPU period towards the management of his assets, so that the debtor's assets are no longer able to allow the continuation of PKPU, then the management is obliged to submit a request for termination of the PKPU, but of course the debtor and management must be heard first by the court, and if this PKPU is terminated based on this, the debtor must be declared bankrupt in the same decision.

The application for termination of PKPU as referred to above must be completed by the court within 10 days and the court's decision must be pronounced within 10 days from the completion of the examination. The court's decision must contain the reasons on which the decision is based. ${ }^{109}$ In addition, the debtor may at any time request the court to revoke the PKPU on the grounds that the debtor's assets allow the resumption of payment of his debts provided that the management and creditors must be summoned and heard properly before the decision is pronounced.

\section{Conclusion}

The appointment of the management is carried out by the panel of judges of the Commercial Court who examines and decides on the PKPU case with a decision and in that decision a supervisory judge is also appointed who oversees the implementation of the management's duties. The administrators appointed are generally in accordance with those requested by the PKPU applicant, except if there is a conflict of interest with the debtor, the panel of judges may appoint another administrator. The requirements to be appointed as a board of directors are the same as those of a curator. Appointed officers must be registered with the Ministry of Law and Human Rights and be independent. The appointment of management in the PKPU decision is regulated in Article 225 paragraph 2 of the Bankruptcy Law and PKPU.

The relationship between PKPU management and PKPU debtors when viewed from their respective authorities is very close, where debtors as company managers cannot act to manage the company, including making loans with the aim of increasing the company's assets to third parties without the knowledge or approval of the PKPU management. Likewise, the PKPU 
management in carrying out their authority so that it can run well and smoothly must always pay attention to and maintain relationships with company management, by establishing good communication, so that there is no misinformation. In carrying out their duties and authorities, the management must always be independent in looking at the interests of debtors and creditors.

The duties and authorities of the PKPU management are regulated in Law Number 37 of 2004 concerning Bankruptcy and Suspension of Debt Payment Obligations. The management's task is to manage the assets of the PKPU debtor with the PKPU debtor, managing the debtor's assets from the beginning until the end of the PKPU with the aim of increasing the value of the assets. During the course of PKPU without the approval of the PKPU management, the debtor cannot take management or ownership actions of all or part of his assets. If it turns out that the PKPU debtor carries out management without the approval of the management, then the management has the authority to do everything necessary to ensure that the debtor's assets are not harmed.

\section{References}

Asikin, Zainal. Bankruptcy Law and Suspension of Payments in Indonesia.

Jakarta: PT. Raja Grafindo Persada, 2001.

Djohan Putro, Bramantyo. Value-Based Corporate Restructuring. Jakarta: PPM, 2004.

Hartini, Rahayu. Bankruptcy Law Revised Edition Based on Law No. 37 of 2004 concerning Bankruptcy and Suspension of Debt Payment Obligations. Malang: Muhammadiyah University Printing, 2008.

Jono, Bankruptcy Law, Bandung: Sinar Graphic, 2009.

Koentjaraningrat. Community Research Methods. Jakarta: Gramedia Pustaka Utama, 1997.

Lontoh, et al. Settlement of Accounts Payable, Through Bankruptcy or Suspension of Debt Payment Obligations. Bandung: Alumni, 2001.

Muhammad, Abdul Kadir. Indonesian Company Law. Bandung: Citra Aditya, 1999.

Munir, Fuady. Bankruptcy Law in Theory and Practice. Bandung: Citra Aditya Bakti, 1999.

Muljadi, Kartini. Bankruptcy and debt settlement Receivables. Bandung: Alumni, 2001.

Sastrawidjaja, Man S. Bankruptcy Law and Suspension of Debt Payment Obligations. Bandung: Alumni, 2006.

Satrio, J. Guarantee Law, Property Guarantee Rights, Mortgage Rights. Bandung: Citra Aditya Bakti, 1998.

Sinaga M, Syamsudin. Indonesian Bankruptcy Law. Jakarta: Tatanusa, 2012. Sjahdeini, Sutan Remy. Bankruptcy Law: Understanding Fallism Verordering,

Juncto Law No. 37 of 2004 concerning Bankruptcy. Jakarta: Graffiti Main Library, 2009. 2010.

Bankruptcy Law (Understanding Law No. 37. 2004 concerning Bankruptcy). Jakarta: Graffiti,

Soekanto, Soerjono. Introduction to Legal Research. Jakarta: UI Press, 1998. Sunarmi. Bankruptcy Law Edition 2. Jakarta: PT. Sofmedia, 2010.

Sutedi, Adrian. Bankruptcy Law. Jakarta: Ghalia Indonesia, 2009. 
Plants, Fred. BG Bankruptcy Law: Settlement of Debts and Receivables through Bankruptcy or PKPU. Bandung: Alumni, 2001.

Law No.37 of 2004 concerning Bankruptcy and Suspension of Debt Payment Obligations.

Government Regulation No. 10 of 2005 concerning Calculation of Creditors' Voting Rights.

Decree of the Minister of Justice of the Republic of Indonesia No. M. 09/HT. 05. 10 of 2008 concerning Guidelines for the Amount of Fees for Curators and Management.

Minister of Law and Human Rights Regulation No.M. 01. HT. 05. 10. 2005 concerning Registration of Curators and Management.

Sri Wijiastuti. "The PKPU Institution As A Means Of Debt Restructuring For Debtors Towards Creditors." Thesis: Masters in Notary Diponegoro University, 2010.

Indonesian Curator and Management Professional Standards, http://sidbers.wordpress.com(accessed September 7, 2013) 